\title{
Diversification of Livelihoods in Urban Informal Settlements in Nairobi, Kenya
}

\author{
Stellah Mong'ina Masese \\ Kenyatta University, Kenya
}

\begin{abstract}
Sustainability of Communities in informal settlements who live in vulnerabilities can be addressed by tapping into the asset bases they have. This in turnis helpful when there is diversification of their livelihoods activities. Diversification of livelihoods is often influenced by many factors, which include but not limited to, seasonality, finance and credit markets, labour market, risk strategies, coping behaviour/adaptation and asset strategies. This paper discusses the influence of financial assets on the diversification of livelihoods in the informal settlements of Nairobi.It is based on a study carried out in Mukuru slums in Nairobi City County which used a cross-sectional study design and was based on a sample of 397 heads of households. It was found out that; men were the majority among the sampled respondents, in which self-employment was the main source of income for the households. As part of securing the livelihoods, challenges were faced while trying to meet the basic needs of monetary income. To address these challenges they relied on different credit sources such as from friends, family and groups. Through these sources they are able to secure their basic needs and also engage in other varied livelihood activities. In order to diversify the livelihoods of slum households there is need to develop and strengthen the different available credit sources and thereby secure a sustainable livelihood for the dwellers of informal settlements.
\end{abstract}

Key words: livelihoods, financial assets, slum, diversification and households

\section{INTRODUCTION}

$\mathrm{T}$ he sustainable development goals (SGD's) aimed at improving different livelihood assets which it will in turn, improve and increase the diversification levels of the said livelihoods assets, both developed and developing countries are coming up with different ways of achieving diversification of livelihoods and improving the livelihood outcomes of individuals and households. SDG goal number one, "ending of poverty and all its forms everywhere by 2030" calls for poverty levels in both developing and developed countries to be reduced. Similarly goal number eight is based on "Promoting sustained, inclusive and sustainable economic growth, full and productive employment and decent work for all". This can be achieved throughbuilding resilienceamong the poor and vulnerable people/ households, to reduce their exposure to vulnerability and different shocks from social, economic or environmental changes that they experience as they seek to fulfil their livelihood needs.

Most of the sources of livelihoods in slum areas are often threatened by various factors, thus making them not sustainable to the households that depend on them to secure their family needs. According to Audefroy (1994), slum households are always faced with the risk of eviction from the places they stay and do business in. This risk often leads to different challenges to the livelihoods of these households as they lack a place to stay and do their business or even access the available livelihood assets, their social networks are destroyed when there is relocation form those areas.Further, according to Davies et al. (2009), disasters and climate changes often influence the attainment of development goals. These disasters often lead to different levels of stress on the available sources of livelihoods and this makes it hard for the people in the slums to move out of the poverty bracket. In order to achieve effective poverty reduction amongst the urban poor there is need to integrated different methods that can lead to strengthening and diversifying of the sources of livelihoods of urban poor and households in the slums.

\section{LITERATURE REVIEW}

According to Carney (1998), livelihoods are sustainable when they are able to cope with and recover from all the stresses and shocks and are able to provide sustainable opportunities that can serve the next generation with benefits both for their short and long term uses. Different shocks and stress often subject households to vulnerabilities that emanate from the prevailing trends that can be triggered by; economic, population, availability of resources, technology and governance factors. On the other hand, shocks can be experienced from climate changes, diseases, seasonality (fluctuations in price of commodities, employment status and conflicts within the household, community or conflicts that affect the whole country). These different scenarios often form a basis for households to try and diversify their different livelihood activities so as to be able to counter different vulnerabilities that they experience.

Ellis(2000)noted that any kind of diversification of livelihoods is often dependent on the following elementswhich usually govern what kind of strategy is appropriate for individuals or households. First, seasonal changes Kabeer (2002: 593), states that some of the general seasonal changes may include increase of food prices and availability of jobs in the labour market thus leading to a change in labour requirements that may in turn impact on the amount of income generated by the household. In urban informal settlements economic seasonality is experienced generally through the temporary labour markets, while at individual or household levels 
seasonal changes and risks may include sudden shocks to the household such as illness/ sickness, divorce or dispossession (Ellis, 2000: 62).

Second, different livelihood strategies could be observed in terms of income received or consumption by households. However, these outcomes could be adversely affected by the occurrence of different livelihood risks from external shocks and stresses and their severity Ellis (2000).Third, the coping mechanisms that are often used when a household is faced with shocks and disasters such as; taking of credits, borrowing from relatives and friends, selling of household assets, depending on food donations and use of accumulated savings (Ellis, 2000).

Fourth, labour markets have been seen as a trigger for diversification of livelihoods. Inthis households adjust to the labour requirements in different ways such as mobilization of available labour within the household, trying to invest in different productive assets and increasing their access to financial services through saving and securing of loans (Banks, 2012). Households are often faced with different structural challenges that hinder their diversification such as hostile labour markets that are characterized by flooded markets that have stiff competition, low remuneration rates, challenging and unhealthy work conditions, seasonal works and intervention of labour markets by intermediaries (Opel, 2000; Roy et al., 2013; Wood \&Salway, 2000).

Fifth, credit access in slum household's isoften faced with lack or difficulties in accessingthe different formal financial institutions that are available in the market. This is often coupled with the lack of appropriate information on their credit worthiness as some don't have any record with those formal institutions together with lack of willing guarantors is a challenge to the slum households (van Bastelaer, 2000). Access to credit and ability to borrow has been reported to encourage diversification of livelihoods Khatun \& Roy (2012).

Six, risky strategies it is assumed that having access to credit encourages use of risky activities through moderation of the liquidity limitation as well as through improving of a household's risk-bearing capacity Simtowe\& Zeller (2006). With a possibility of borrowing at their disposal, households are able to do away with unproductive risk reducing income diversification approaches and focus on more risky but also more effective investments that can lead to higher returns Simtowe\& Zeller (2006).

All these financial assets are explained through borrowing ideas from rational choice theory also known as choice theory or rational action theory that was developed by George Homans (1961). It aims at understanding the social and economic behaviour of individuals in a society. Individuals are seen to be motivated by their wants or goals that support their preferences. Homans argued that this was the driving factor on how individuals acted, within specific and given constraints, based on the information they have on the conditions they are acting in. Leading them to make choices on their goals and means for attaining those needs and wants. Rational individuals choose the alternative that is likely to give them the greatest satisfaction (Coleman (1973), Heath 1976 \& Carling 1992).

\section{Focus of this paper}

This paper focuses on the influence of financial assets on diversification of livelihoods of households in Mukuru informal settlements in Nairobi Kenya. According to Lasse, (2001), diversification of livelihoods has been seen to have an important connection to the financial assets. Financial assets have over time been seen as the most versatile asset among the five livelihood assets advocated by Department for International Development (DFID). This is because they have the capacity to be easily transformed into other types of assets and can also be used to attain different livelihood outcomes directly (such as purchasing of food so as to reduce food insecurity in a household). Unfortunately, financial assets are the least available assets to the poor households thus making the other capitals imperative as they can act as alternatives (Kollmair and Juli, 2002).

\section{METHODOLOGY}

The data presented and discussed in this paper is from a largerstudy that adoptedfrom a descriptive cross sectional survey designand used bothqualitative and quantitative methodsduring the collection and analysis of data.

The sample size was determined using Yamane sample estimation framework of 1967. The sample size was 397 households.The sampling process had the following stages; Firstly, Mukuru slum was purposively sampled due to its high household population (of 44,427 according to KNBS data of 2009) and because of its proximity to different manufacturing industries. Secondly, cluster sampling was used to group the twenty (20) villages; from this three clusters were developed based on the population size. The first cluster was for villages with small populations, the second cluster had medium sized populated villages, while the third cluster was for most populous villages. Thirdly from the three clusters, two villages were selected from each cluster using simple random sampling. Fourthly the key informants and focus group discussants were purposively sampled.

Analysis of data was doneusing quantitative and qualitative approacheswith the help of Statistical Package for Social Sciences (SPSS) V 22, to come up with the frequencies, logistical regression model that was used to identify determinants that influenced the household's decision on diversification of livelihoods. Chi-square was used to determine relation between variables of the paper.All FGDs and key informants interviews were thematically analysed as per the objectives of the paper. In conducting the study all ethical considerations such as informed consent, confidentiality as well as care and protection of the participants were ensured. Data was protected through 
passwords. Regulatory and ethical clearances were also obtained.

\section{RESULTS}

\section{Social Demographic and Economic Characterises of} Respondents

Table 4.1 presents data on the social demographic and economic characteristics of the 397 respondents who took part in this study.

Table: 4.1 Social Demographic and Economic Characterises of Respondents

\begin{tabular}{|c|c|c|c|}
\hline Variable & & Frequency & Per cent \\
\hline \multirow{2}{*}{$\begin{array}{c}\text { Sex } \\
N=397\end{array}$} & Male & 201 & 50.6 \\
\hline & Female & 196 & 49.4 \\
\hline \multirow{5}{*}{$\begin{array}{c}\text { Age } \\
\mathrm{N}=397\end{array}$} & $18-28$ & 190 & 47.9 \\
\hline & $29-39$ & 155 & 39.0 \\
\hline & $40-50$ & 42 & 10.6 \\
\hline & $51-60$ & 7 & 1.8 \\
\hline & Above 61 & 3 & .8 \\
\hline \multirow{5}{*}{$\begin{array}{l}\text { Marital status } \\
\quad \mathrm{N}=397\end{array}$} & Married & 284 & 71.5 \\
\hline & Single & 97 & 24.4 \\
\hline & Divorced & 8 & 2.0 \\
\hline & Separated & 7 & 1.8 \\
\hline & Widowed/ Widower & 1 & .3 \\
\hline \multirow{5}{*}{$\begin{array}{c}\text { Educational } \\
\text { level } \\
\mathrm{N}=397\end{array}$} & Secondary & 210 & 52.9 \\
\hline & Primary & 116 & 29.2 \\
\hline & Tertiary & 45 & 11.3 \\
\hline & University & 18 & 4.5 \\
\hline & No formal education & 8 & 2.0 \\
\hline \multirow{3}{*}{$\begin{array}{c}\text { Current } \\
\text { Occupational } \\
\text { Status } \\
\mathrm{N}=397\end{array}$} & Self-employed & 228 & 57.4 \\
\hline & Employed & 163 & 41.1 \\
\hline & Unemployed & 6 & 1.5 \\
\hline
\end{tabular}

From Table 4.1 it can be seen that; one, majority of the sampled respondent were men at 50.6 per cent, while women accounted for 49.4 per cent. Two, on age 18-28 years old were the majority accounting for 47.9 per cent, followed by those of 29-39 years old at 39.0 per cent, $40-50$ years old were third with 10.6 per cent, 51-60 years with 1.8 per cent and above 61 years at 0.8 per cent.It can be concluded thatmajority are less than forty years old. Three, on marital status majority of respondents were married ( 71.5 per cent), while 24.4 per cent were single. The divorced, separated and widowed and widower were 2.0 per cent, 1.8 per cent, 0.3 per cent respectively. Four, for educational levels majority of the respondents (52.9 per cent) had a secondary school level qualification while 29.2 per cent primary level. Based on these results it can be deduced that majority of respondents had some modest educational qualification, and at best were literate. Lastly, on the occupational status of the respondents, self-employed respondents were the majority with a percentage of 57.4 per cent, followed by those employed at 41.1 per cent and unemployed at 1.5 per cent. From these results it was noted that self- employment was the most preferred mode of occupation for the respondents. A Business Leader (one of the key informants in Vietnam area) acknowledged that majority of the people living in Mukuru were self-employed in a wide variation of activities.

\section{Influence of Financial Assets on Diversification of Livelihoods}

Financial assets are key components in development and sustainability of household livelihoods. The paper explored the kind of activities respondents were involved in either as their main source or a supplementary to the main source of income, the amount of money they earned at the end of the month and lastly how they engaged in financial borrowing in order to cope and boost their financial capacity to support their livelihoods.

\section{Sources of Income}

In this paper sources of income were divided into two: -main sources and other sources of income for the households, as shown in table 4.2.

Table 4.2: Main Source of Income and Other Sources of Income

\begin{tabular}{|c|c|c|c|c|c|}
\hline \multicolumn{2}{|c|}{ Main Source of Income } & \multicolumn{3}{c|}{ Other Sources of Income } \\
\hline $\begin{array}{c}\text { Categor } \\
\text { y }\end{array}$ & $\begin{array}{c}\text { Frequ } \\
\text { ency }\end{array}$ & $\begin{array}{c}\text { Per } \\
\text { cent }\end{array}$ & Source & $\begin{array}{c}\text { Freque } \\
\text { ncy }\end{array}$ & $\begin{array}{c}\text { Per } \\
\text { cent }\end{array}$ \\
\hline $\begin{array}{c}\text { Self- } \\
\text { employ } \\
\text { ed }\end{array}$ & 228 & 57.4 & $\begin{array}{c}\text { Business (Food } \\
\text { kiosks, kerosene, } \\
\text { clothes, soap } \\
\text { making) }\end{array}$ & 50 & 61.3 \\
\hline $\begin{array}{c}\text { Casual } \\
\text { wage } \\
\text { Employ } \\
\text { ment }\end{array}$ & 163 & 41.1 & $\begin{array}{c}\text { Casual jobs } \\
\text { (Welding, } \\
\text { electrician, } \\
\text { laundry cleaning) }\end{array}$ & 18 & 22.6 \\
\hline $\begin{array}{c}\text { Unemp } \\
\text { loyed }\end{array}$ & 6 & 1.5 & $\begin{array}{c}\text { Farming (outside } \\
\text { the slum area) }\end{array}$ & 8 & 10.1 \\
\hline Total & 397 & 100.0 & $\begin{array}{c}\text { Social networks } \\
\text { ( Husband and } \\
\text { groups) }\end{array}$ & 3 & 3.8 \\
\hline & & \multicolumn{1}{|c|}{ Total } & 79 & 100.0 \\
\hline
\end{tabular}

\section{i. Main Sources of income}

Results from the study show that self-employment; specifically in business was the leading source of income at 57.4 per cent and casual wage employment at 41.1 per cent. Majority of the respondents secured their income by engaging in different self- employment business activities such as green grocery, street food cooking, retail shop, charcoal, barber and salon and from being a casual labourer.

This was corroborated by qualitative data. According to the Senior Chief for Mukuru KwaNjenga slum (5 years in Mukuru as a Senior Chief) noted that the main sources of income in the area were from business such as shops/ kiosks, street cooking and hotels, hawking of clothes and household goods, illicit brew and water vendors. Another key Informant 
Religious leader) also pointed out that most common livelihood activities in the area were from company employment in industrial area, self- employment in areas like having a green grocer, shops, tailoring, street cooking and engaging in casual jobs, such as, laundry services and garbage collection.

On the other hand theFocus group discussants from the three groups(women, men, mixed groups)listed the following as the main sources; businesses, company employment, construction jobs, water vendors. These findings are in line with findings of UN-Habitat (2003) report on the challenges of slums which found out that most households in developing countries' slums earn their income from informal employment activities that are within and outside the slum. The study established that most of the slum dwellers households' are involved in low-paying employments such as informal jobs in the clothing industry, a variety of home-based activities and several are domestic servants, security guards and self-employed such as hair dressers and furniture fabricators. Thus the informal sector has become the dominant livelihood source in slums. It can be concluded that the informal livelihoods activities are important for sustainability of livelihoods.

\section{ii. Other Sources of Income}

In as much as respondents had a main source of income, because of their main source of income being inadequate, at least seventy nine respondents were found to have another source of income to supplement their main source of income. The study established that majority ( 61.3 per cent) of the respondents engaged in business activities as an alternative source of income, 22.6 per cent engaged in casual jobs within the area 10.1 per cent were involved in farming activities back in their rural areas.

\section{Incomes Earned from Main and Other Sources of Income}

\section{i. Main Source of Income}

It was found out that 39.8 per cent earned between 10,000 to 19,000 shillings, followed by those earning less than 10,000 shillings at 20.7 per cent. Those earning between 20,000 to 29,000 shillings were a third at 18.9 per cent, while those earning 30,000 to 39,000 were 13.9 per cent.

\section{ii. Other Sources of Income}

Other sources of income had the following percentages in the monies earned; majority earned less than 10,000 shillings per a month which accounted for 58.2 per cent followed by 10,000 to 19,000 shillings at 26.5 per cent and above 50,000 shillings at 7.5 per cent.

However based on the above sources of income and amount of income generated from those activities Mukuru households are often faced with different vulnerabilities that emerge from a variety of issues, and they often try to cope in different ways; such as using the different livelihoods assets that are at their disposal and within the constraints and choices that enable them to pursue diverse livelihood strategies for better outcomes.

\section{Livelihood Vulnerabilities, Threats and Coping Strategies of Households}

Some of the most experienced threats and shocks were associated with sickness at 45.6 per cent, loss of a source of income at 34.5 per cent and crime at 23.7 per cent. These findings are in line with Moser (1998) \& Gupte (2011), who argue that vulnerability of the urban poor is due to the different circumstances that they face in asset deficit, such as, having a low and unstable income base, lack of proper sanitation and insecure living space, and due to some social distance that is expressed in reducing of support networks from the communities and families. It can be said that these threats and shocks basically impact themnegatively thus making them vulnerable to different livelihood challenges hence less achievement of their desired livelihood outcomes. One of the challenges is on securing of the basic needs for the household.

\section{Challenges in Meeting Basic Needs}

Financial assets are volatile in nature, due to these respondents' experienced different kinds of challenges when trying to fulfil their basic needs. These were the challenges listed by respondents as shown in table 4.3.

Table 4.3: Challenges in Meeting Basic Needs

\begin{tabular}{|c|c|c|}
\hline Challenges & $\begin{array}{c}\text { Frequenc } \\
\text { y }\end{array}$ & Per cent \\
\hline $\begin{array}{c}\text { Lack of money ( Delay in payments, bad } \\
\text { credits, low wages, }\end{array}$ & 168 & 57.5 \\
\hline Too many needs/ dependants & 42 & 14.1 \\
\hline $\begin{array}{c}\text { Unpredictable market (Lack of customers, } \\
\text { low profit margins and Demolitions / Lack } \\
\text { of business space) }\end{array}$ & 40 & 13.5 \\
\hline Lack of jobs/ source of income & 36 & 12.3 \\
\hline Sickness & 3 & 1.0 \\
\hline Environmental changes & 3 & .9 \\
\hline Total & 292 & 100.0 \\
\hline
\end{tabular}

From table 4.3 households that experienced challenges that were relatedto lack of money werethe majority at 57.5 per cent of the sampled respondents, followed by 14.1 per cent that had too many household needs and challenges from unpredictable market at 13.5 per cent. Lack of money was attributed to delay in payments, unpaid credits and low wages. This translated to household heads lacking enough or no money to cater for their household expenses. Firstly, according to a business leader (a key informant) who operates a number of businesses in Vietnam Village in Mukuru KwaNjenga, most businessmen/ladies don't get enough money from their businesses mostly due to business duplication that is very high in the area whereby there are a lot of similar businesses in close proximity thus leading to lack of customers for their products and services that is also 
accelerated by bad debts. Also as part of the challenges, there is lack of enough jobs for the huge slum population in the area - and this has limited the number of people who are able to secure a job thus leading to lack of income for the household.

Secondly, both the Religious Leader and Community Based Organization Representatives also noted that lack of basic needs provision is also due to many household needs in which most households have a lot of dependants and lack of jobs in the area. Thirdly, both the men and Women focus group discussants also stated that bad credits and, poor payments are the main challenges experienced by the people in Mukuru thus not being able to cater for their basic needs and that of the household. Equally, unpredictable market trends was a challenge too as some of the business people faced a lot of competition leading to some of their stock getting spoilt when they are not purchased by their customers and having covetous business competitors around them who feel that the neighbour's business is doing better than theirs some end up experiencing theft and vandalism of their businesses. Thefindings are in line with other related literature. For instance, according to Ruel M, Garrett J, Morris SS, et al. (1998), majority of urban slum households buy their own food from the local area markets in which lack of income is often the main challenge to them thus hindering them the provision of food to their households. These scenarios are experienced in different slum areas in Nairobi which are characterized by high levels of either being unemployed or underemployed, insecure livelihoods, lack of basic amenities and social services Faye, O., Baschieri, A., Falkingham, J., \&Muindi, K. (2011).

\section{Coping with Loss of a Source of Income and Provision of} Basic Needs

From the one hundred and thirty seven (137) respondents had experienced loss of a source of income which had a negative impact on provision of basic needs. As part of coping in order to meet the basic needs for the household. At least 41.6 per cent coped by looking for another job or by engaging in casual jobs, while another 15.3 per cent had to borrow from friends so as to meet their needs and 12.4 borrowed or depended on the support of their families. The findings are in line with those of Dhanaraj, S. (2016)'s research on economic vulnerability to health shocks and coping strategies where lack or loss of a source of income was seen to be a common occurrence for different households. This often led them to seek for credit services where majority of households often relied on informal sources of credit that are available in their area such as moneylenders, friends and relatives. It can be concluded that one, in order to achieve sustainable livelihoods outcomes one needs to have different sources of income that help in meeting the different requirements of the households. Two, loss of a source of income has an impact on the threats/shocks that emerge from sickness in that as one gets sick they need to seek medication which normally requires money. Thus as they lack money and fail to seek medication it them affects their different sources of income.

\section{Financial Borrowing/Credits as a Coping Strategy}

Based on the different vulnerabilities, shocks and challenges that households experience they end up engaging in some credit borrowing so as to have some financial assets in terms of money. The paper found out that there were different sources of credit that head of households borrowed from. Credit was obtained mainly from friends ( 47.6 per cent), other significant sources included family (21.7 per cent), Group/ Chama (21.4 per cent) and from loans either from a bank or through the mobile phone application (10.6 per cent)

Discussants from all the three groupsagreed that they always borrow from varied sources such as; their friends, families, from groups (chama) and shylock agents, from also phone applications such as Tala, Branch and $\mathrm{M}$ shwari.From the findings it is important to note that social capital was an important base for obtaining credit as majority of 90.7 per cent borrowed from friends 47.6 , from family 21.7 and 21.4 per cent from groups. These findings and discussions were in line with the study of Kenya Integrated Household Budget Survey(KIHBS) (March 2018), that found out that majority of the Kenyans borrowed money or sort credit from different informal sources such as from neighbours, friends, relatives, or from local money lenders or shylocks. In which some could borrow money or take credit services from the shops in order to repay at a later date. This basically meant that the households borrowed or sought credit so as to be able to cater for their individual basic needs and those of the entire household.

Subsequently different uses were reported on how money borrowed from groups and financial institutions was spent by respondents; for groups 13.4 per cent used it for business gains, 10.8 per cent for general expenses and 10.1 per cent for specifically for school fees. While of those who borrowed from financial institutions 35.9 per cent used the money to secure for their basic needs, 30.4 per cent used it to start a business and boosting of the current established businesses and 21.7 per cent used it for purchase of assets (cow, land, sunk a borehole, house construction, water tanks). This results are in line with KIHBS (March 2018) report, which shows nationally at least 39.3 per cent of the loans were obtained for subsistence needs and school fees 20.9 per cent. It was found out that loans from shops and mobile phone platforms were mainly used for subsistence needs while loans from financial institution were used for different business or investment activities. From the foregoing, it can be concluded that majority of respondents use borrowed monies to develop their livelihoods through the different business activities that they get involved in while some percentage too used if for provision of basic needs.

In conclusion it is evident that all the financial assets were in one way connected to provision of basic and also some towards diversification of livelihoods such as start and boosting of businesses. All these are geared towards dealing with sustainable sources of income and provision of needs. 


\section{Financial Assets and Livelihood Diversification}

\section{Household Dependants and Expenses}

From the above income sources (main, other sources and financial borrowing/credit) the paper sought to find out the number of people in a household, how income was generated and spent. First, majority of households sampled had dependants; households with more than four dependants were the majority at 28.8 per cent, two dependants at 25.7 per cent and those with three dependants at 19.1 per cent. Second, most livelihoods were secured by an individual at 63.0 per cent, followed by those secured by two people at 32.7 per cent.

From these household expenses were explored so as to determine whether they had any influence on diversification of livelihoods. Five types of household expenses were explored; food, rent, water, school fees and health that are incurred as they seek and develop their different livelihoods in the area and beyond. As shown in Table 4.4.

Table 4.4: Household Expenses per a Month

\begin{tabular}{|c|c|c|c|}
\hline \multirow{6}{*}{$\begin{array}{l}\text { Food } \\
\mathrm{N}=397\end{array}$} & Amount inUSD (\$) & Frequency & Per cent \\
\hline & $0-\quad 10$ & 22 & 5.5 \\
\hline & $10-50$ & 126 & 32.2 \\
\hline & $50-10$ & 177 & 44.6 \\
\hline & $10-20$ & 69 & 17.4 \\
\hline & Above 21 & 3 & .8 \\
\hline \multirow{7}{*}{$\begin{array}{l}\text { Water } \\
\mathrm{N}=397\end{array}$} & Amount in USD (\$) & Frequency & Per cent \\
\hline & $\begin{array}{c}0 \text { (Water vendor/ owns a } \\
\text { water point) }\end{array}$ & 10 & 2.5 \\
\hline & $1-5$ & 227 & 57.2 \\
\hline & $5-10$ & 110 & 27.7 \\
\hline & $1-15$ & 26 & 6.5 \\
\hline & $15-20$ & 11 & 2.8 \\
\hline & Above 20 & 13 & 3.3 \\
\hline \multirow{10}{*}{$\begin{array}{c}\text { Rent } \\
\mathrm{N}=397\end{array}$} & Amount in USD (\$) & Frequency & Per cent \\
\hline & 0 (Owns a house) & 14 & 3.5 \\
\hline & $1-\quad 15$ & 29 & 7.3 \\
\hline & $15-20$ & 122 & 30.4 \\
\hline & $201-25$ & 98 & 24.6 \\
\hline & $25-30$ & 59 & 14.9 \\
\hline & $301-35$ & 13 & 3.3 \\
\hline & $35-40$ & 23 & 5.8 \\
\hline & $40-10,0$ & 30 & 7.5 \\
\hline & Above 10,0 & 9 & 0.7 \\
\hline \multirow{4}{*}{$\begin{array}{l}\text { Health } \\
\mathrm{N}=397\end{array}$} & Amount in USD (\$) & Frequency & Per cent \\
\hline & NHIF-500 (Self) & 120 & 30.2 \\
\hline & NHIF-800 (Company) & 23 & 5.8 \\
\hline & 0 & 92 & 23.2 \\
\hline
\end{tabular}

\begin{tabular}{|c|c|c|c|}
\hline & $1-50$ & 34 & 8.6 \\
\hline & $50-10$ & 52 & 13.1 \\
\hline & $10-20$ & 36 & 9.1 \\
\hline & 20- 30 & 22 & 5.5 \\
\hline & Above 30 & 18 & 4.5 \\
\hline \multirow{8}{*}{$\begin{array}{c}\text { School } \\
\text { fees } \\
N= \\
397\end{array}$} & Amount in USD (\$) & Frequency & Per cent \\
\hline & 0 & 132 & 33.2 \\
\hline & $1-1000$ & 81 & 20.4 \\
\hline & $1001-2000$ & 49 & 12.3 \\
\hline & 2001- 3000 & 25 & 6.3 \\
\hline & $3001-4000$ & 20 & 5.0 \\
\hline & $4001-5000$ & 26 & 6.5 \\
\hline & Above 5001 & 64 & .3 \\
\hline
\end{tabular}

From the above expenses some were found to be statistically significant to diversification of livelihoods by the different households in Mukuru slums. The tables below showexpenses that werestatistical significant to diversification of livelihoods in Mukuru.

Table 4.5: Household Expenses and Diversification of Livelihoods

\begin{tabular}{|c|c|c|c|c|c|}
\hline $\begin{array}{c}\text { Type of } \\
\text { Expense }\end{array}$ & Method & $\begin{array}{c}\text { Varian } \\
\text { ces }\end{array}$ & DF & $\begin{array}{c}\mathrm{t} \text { Valu } \\
\mathrm{e}\end{array}$ & $\operatorname{Pr}>|\mathrm{t}|$ \\
\hline \multirow{3}{*}{ School Fees } & Pooled & Equal & 387 & 3.06 & 0.0024 \\
\cline { 2 - 6 } & $\begin{array}{c}\text { Satterthw } \\
\text { aite }\end{array}$ & $\begin{array}{c}\text { Unequ } \\
\mathrm{al}\end{array}$ & $\begin{array}{c}380.4 \\
5\end{array}$ & 3.28 & $\begin{array}{c}0.0011^{*} \\
* *\end{array}$ \\
\hline \multirow{3}{*}{ Rent } & Pooled & Equal & 387 & 2.27 & 0.0235 \\
\cline { 2 - 6 } & $\begin{array}{c}\text { Satterthw } \\
\text { aite }\end{array}$ & $\begin{array}{c}\text { Unequ } \\
\text { al }\end{array}$ & $\begin{array}{c}320.6 \\
7\end{array}$ & 2.55 & $0.0112^{*}$ \\
\hline \multirow{3}{*}{ Water } & Pooled & Equal & 387 & 2.18 & 0.0302 \\
\cline { 2 - 6 } & $\begin{array}{c}\text { Satterthw } \\
\text { aite }\end{array}$ & $\begin{array}{c}\text { Unequ } \\
\text { al }\end{array}$ & $\begin{array}{c}344.6 \\
7\end{array}$ & 2.41 & $0.0166^{*}$ \\
\hline
\end{tabular}

\section{i. School Fees}

Household expenses that related to school matters were the most significant with a $\mathrm{P}$ value of 0.0011 . This can be interpreted in two ways, one majority of the household heads were between the ages of 18-28 years and majority were married which meant that they had school going children that need money for the different school activities. Secondly, the number of dependants too who the majority were children also led to diversification of livelihoods as they try to provide the basic need of education.

\section{ii. Rent}

Rent was significant with a $\mathrm{P}$ value of 0.0112 to diversification of livelihoods in among other household expenses. This can be explained with reference to the number of dependents per a household head in which the paper found out that majority had more than one dependent. Thus the need to secure shelter for the dependents leading to household 
heads having to look for ways of generating some income in which some engaged in more than one livelihood activity.

\section{iii. Water}

Water as a basic need was significant $\mathrm{P}$ value 0.0166 . With a majority being married, many dependants per a household then there was increase in the amount of water used per a household to prepare meals and for general cleanliness of the household.

From the above, only three basic needs were found to be statisticallysignificant (rent, water and school fees) in relation to diversification of livelihoods as they were found to be most pressing needs for households. This can be also be linked with the aspect of the number of dependants on the household head often determines how big or small the family size will be. According to Asfir, (2016); Tamerat, (2016); Mentamo\&Geda, (2016), this usually affects diversification of livelihoods positively due to the presence of huge families to run through the multiple livelihood activities that lead to diversification of their livelihood strategies and also the different needs that have to be met.

\section{Hypothesis Testing}

From the above different activities that are involved with financial matters in households, the paper sought to test a hypothesis $\mathrm{Ho}_{1}$ : Financial assets have no effect on livelihood diversification. Different statistical analyses were done in order to establish whether there was a relationship between the two variables the financial assets and diversification in Mukuru slums.

Table: 4:6: Chi- Square Testing for Financial Assets and livelihood diversification.

\begin{tabular}{|c|c|c|c|c|c|}
\hline \multicolumn{6}{|c|}{ Analysis of Maximum Likelihood Estimates } \\
\hline Parameter & DF & $\begin{array}{c}\text { Estimat } \\
\mathrm{e}\end{array}$ & $\begin{array}{c}\text { Stand } \\
\text { ard } \\
\text { Error }\end{array}$ & $\begin{array}{c}\text { Wald } \\
\text { Chi- } \\
\text { Square }\end{array}$ & $\begin{array}{c}\text { Pr > Chi } \\
\text { Sq }\end{array}$ \\
\hline Intercept & 1 & 6.1347 & $\begin{array}{c}3.185 \\
5\end{array}$ & 3.7088 & 0.0541 \\
\hline $\begin{array}{c}\text { Borrow from } \\
\text { friends }\end{array}$ & 1 & -0.4589 & $\begin{array}{c}0.230 \\
2\end{array}$ & 3.9751 & $\begin{array}{c}0.0462^{*} \\
*\end{array}$ \\
\hline $\begin{array}{c}\text { Borrow from } \\
\text { family }\end{array}$ & 1 & 0.0361 & $\begin{array}{c}0.267 \\
2\end{array}$ & 0.0183 & 0.8924 \\
\hline $\begin{array}{c}\text { Borrow from } \\
\text { neighbours }\end{array}$ & 1 & -0.1061 & $\begin{array}{c}0.783 \\
6\end{array}$ & 0.0183 & 0.8923 \\
\hline $\begin{array}{c}\text { Borrow from } \\
\text { group/ chama }\end{array}$ & 1 & -0.4671 & $\begin{array}{c}0.280 \\
0\end{array}$ & 2.7821 & $0.0953^{*}$ \\
\hline $\begin{array}{c}\text { Borrow from } \\
\text { bank }\end{array}$ & 1 & -0.5014 & $\begin{array}{c}0.360 \\
1\end{array}$ & 1.9381 & 0.1639 \\
\hline $\begin{array}{c}\text { Borrow a loan } \\
\text { on item }\end{array}$ & 1 & -1.5979 & $\begin{array}{c}1.113 \\
7\end{array}$ & 2.0586 & 0.1514 \\
\hline
\end{tabular}

The above test, the level of confidence was lowered to 90 per cent at a $P$ value of 0.1 because majority of the household heads did not engage in any borrowing. For this test credit borrowing sources from friends with a value of 0.0462 and chama/ groups at 0.0953 were found to be the most significant among the heads of household. Therefore the hypothesis is rejected as it was found out that the different credit sources had an effect or influence on diversification of livelihoods in Mukuru slums.

Thus the two credit sources groups/ chama and friends should be strengthened as they encourage head of households to diversify their livelihoods. Based on this it can be said in order for diversification of livelihoods to occur in Mukuru slums then there is need for strengthening of credit sources and advocating of proper use for the monies borrowed from any of the two sources.

However with all these sources and uses of the money borrowed some head of households preferred not to borrow from groups or financial institutions. Majority (45.5 per cent) of those who did not borrow from groups was because they were in groups that were not meant for borrowing as part of their group activities, 25.9 per cent did not have pressing needs that could subject them to borrow, while at least 16.9 per cent the fear of high interest rates on the money borrowed. While those that borrowed from financial institutions, 23.8 per cent did not have pressing needs to trigger them to borrow, 21.9 per cent due to lack of collateral and 20.9 per cent did not own a bank account. According to the mixed group discussants they also agreed to these reasons of not being able to borrow because they have no/ lack business knowledge, thus they see no need for borrowing. Secondly, the do not borrow from financial institution as they do not have bank accounts with the local banks as they believe that banks and saccos are for those that have a lot of money and can be able to save. AlsoMukuru's Senior Chief expressed that, as part of not being able to borrow the issue of women lacking national identification cards was the main challenge in that most of women in the area do not have national identification cards thus making it hard for them to access some services such being able to open a bank account (national identification card is one of the requirements) this consequently leads to not being able to borrow from financial institutions. Other aspects like no need to borrow were basically due to lack of financial knowledge such they don't have any plan on what they can do with the money.

These findings are in line with those of Hari. S (2016), "14 Reasons why the Informal Credit Market is used by the Poor: Policy Implications for Microcredit Programmes in Developing Countries". The paperfound out the following; one, strict requirements for acquiring credit/ loans from financial institutions had continuously led to low uptake of credit services by low income households. More often the banks require borrowers to have a source of income that has a "stable" income flow whereas most of these households earn their incomes from informal sector jobs that always keep their incomes very irregular and uncertain. Secondly the banks also require the borrowers to have some collateral which can be inform of a land ownership title / certificate which again is not readily available as most do not own land. Groups too require one to be a member and to have some savings in the group, to enable him or her to take credit against their savings). 
Therefore it can be deduced that for one to acquire credit either from a group or a financial institutions different requirements have to be met by the borrower. In the event those requirements are not met it leads to low uptake of credit services.

\section{CONCLUSION}

It was concluded that financial assets are key in the pursuit of sustainable livelihoods. It was also noted that these financial assets are basically secured from the different sources of income either from self-employed or employed of from the different borrowing. Based on the different household expenses water, school fees and rent were found to be the main triggers for the desire by households to diversify their sources of income. Also in order to have sustainable livelihoods in informal settlement and society there is need for strengthened financial assets as they are the main determining factor for sustainability of livelihoods and have a greater influence on the other livelihood assets.

\section{RECOMMENDATION}

It was concluded that income and credit sources in the informal settlement should be strengthened so as to enable sustainable and diversified livelihoods in the area and within the households.

\section{REFERENCES}

[1] Asfir S (2016). Determinants of Rural Households Livelihood Strategies: Evidence from Western Ethiopia. Journal of Economics and Sustainable Development 7(15):103-109.

[2] Audefroy, J (1994). 'Eviction trends world-wide - and the role of local authorities in implementing the right to housing'. Environment and Urbanization, vol 6, no 1, pp8-24.

[3] Banks, N. (2012). 'Urban Poverty in Bangladesh: Causes, Consequences and Coping Strategies'. BWPI Working Paper No. 178. Manchester: University of Manchester.

[4] Carling, A. (1992). Social Divisions. London: Verso.

[5] Carney, D., Ed. (1998). Sustainable Rural Livelihoods: What Contribution Can We Make? DFID, London.

[6] Coleman, J. (1973). The Mathematics of Collective Action. London: Heinemann.

[7] Davies, M., Guenthier, B., Leavy, J., Mitchell, T. and Tanner, T. (2009). Climate Change Adaptation, Disaster Risk Reduction and Social Protection: Complementary Roles in Agriculture and Rural Growth? Working Paper 320. Brighton: Centre for Social Protection and Climate Change and Development Centre, IDS.

[8] Dhanaraj, S. (2016). Economic vulnerability to health shocks and coping strategies: evidence from Andhra Pradesh, India, Health Policy and Planning. Volume 31, Issue 6, July 2016, Pages 749758, https://doi.org/10.1093/heapol/czv127.

[9] Faye, O., Baschieri, A., Falkingham, J., \&Muindi, K. (2011). Hunger and food insecurity in Nairobi's slums: an assessment using IRT models. Journal of urban health: bulletin of the New York Academy of Medicine, 88 Suppl 2(Suppl 2), S235-S255. doi:10.1007/s11524-010-9521-X.
[10] Gupte, J. (2011). 'Extralegal Security and Policing for the Urban Dispossessed in Mumbai'. $\quad$ in R. Desai and R. Sanyal (eds), Urbanizing Citizenship: Contested Spaces in Indian Cities, New Delhi: Sage

[11] Heath, A. (1976). Rational Choice and Social Exchange. Cambridge: Cambridge University Press.

[12] Kabeer, N. (2002). Safety nets and Opportunity Ladders: Addressing Vulnerability and Enhancing productivity in South Asia. Development Policy Review, 2002, 20(5): 589 - 614.

[13] Kenya Integrated Household Budget Survey (March 2018). Basic Report Based on 2015/16 Kenya Integrated Household Budget Survey. Kenya National Bureau of Statistics - Ministry Of Devolution \& National Planning. KEN-KNBS-KIHBS-20152016-v01.

[14] Khatun D, Roy BC (2012). Rural livelihood diversification in West Bengal: determinants and constraints. Agricultural Economics and Research Review, 25(1), 115-124.

[15] Kollmair, M. and Juli, St. Gamper. (2002). The Sustainable Livelihoods Approach, Development Study Group. University of Zurich (IP6).

[16] Lasse K, 2001. The Sustainable Livelihood Approach to Poverty Reduction. International Development Cooperation Agency, Sweden.http://www.forestry.umn.edu/prod/groups/cfans/@pub/@ cfans/@forestry/documents/ asset/cfans_asset_202603.pdf.

[17] Mentamo M, Geda N (2016). Livelihood diversification under severe food insecurity scenario among smallholder farmers in KadidaGamela District, Southern Ethiopia.Kontakt 18(4):289295. http://dx.doi.org/10.1016/j.kontakt.2016.09.003

[18] Moser, C. O. (1998). The asset vulnerability framework: reassessing urban poverty reduction strategies. World Development, 26 (1): 1-19.

[19] Roy, M., Hulme D. \&Jahan F. (2013). 'Contrasting Adaptation Responses by Squatters and Low-income Tenants in Khulna, Bangladesh.Environment and Urbanization25 (1): 157-76.

[20] Ruel M, Garrett J, Morris SS, et al. (1998). Urban challenges to food and nutrition security: a review of food security, health, and caregiving in the cities. Washington: Food Consumption and Nutrition Division, International Food Policy Research Institute.

[21] Simtowe, F., Zeller, M. (2006). The impact of access to credit on the adoption of hybrid maize in Malawi: an empirical test of an agricultural household model under credit market failure. Munich Personal RePec Archive (MPRA) Paper No. 45, September 2006.

[22] Opel, A.E.A.(2000). 'The Social Content of Labour Markets in Dhaka Slums'.Journal of International Development12 (5): 735 50.

[23] Srinivas, Hari. (2016). "14 Reasons why the Informal Credit Market is used by the Poor: Policy Implications for Microcredit Programmes in Developing Countries". GDRC Research Output E-111. Kobe, Japan: Global Development Research Center. Retrieved from http://www.gdrc.org/icm/14reason.html on Wednesday, 25 September 2019.

[24] United Nations Human Settlements Programme (UN-Habitat) (2003). The challenge of slums: global report on human settlements. Earthscan

[25] Van Basteaer, T., (2000). "Imperfect Information, Social Capital and the Poor's Access to Credit" Center for institutional reform and the informal sector. Working paper No 234: University of Maryland.

[26] Wood, G.\&S. Salway(2000). 'Introduction: Securing Livelihoods in Dhaka Slums', Journal of International Development12 (5): 669-88. 